\title{
Currency Wars?
}

"War is not merely a political act, but also a political instrument, a continuation of political relations, a carrying out of the same by other means." This working definition of war by the 19th century Prussian military historian Clausewitz is widely accepted even today. If the notion that "quantitative easing is a continuation of monetary policy by other means" is added to this, the use of the term "currency wars" becomes understandable.

Who started this "war"? The easy answer is the USA. With short-term interest rates already at zero and fiscal policy possibly paralysed by a divided government, the Federal Reserve recently opted for a programme of buying $\$ 600$ billion of medium-term Treasury bills with the aim of stimulating demand via lower interest rates.

Why did it chose to do so and will this policy work?

The why is clear. Part of the mandate of the Fed is to aim for high employment. This is why it feels that it has to do "something", or rather anything, to stimulate demand in order to reduce unemployment, which is at a politically unacceptable level (9.5\%). It is interesting to note that growth has recovered more strongly in the USA than in the euro zone this year (to over 3\% in Q3), but still the Federal Reserve maintains that it has to engage in quantitative easing because it considers the present unemployment rate unacceptable. By contrast, the ECB has recently even been talking about withdrawing some stimulus although the growth rate in the euro area, at below $2 \%$, is considerably below that of the USA, and the euro area unemployment rate is still above $10 \%$, and thus higher than the US rate. This shows the extent to which the acceptability of unemployment differs on both sides of the Atlantic.

Will it work? The essence of quantitative easing is that buying massive amounts of Tbills should lower medium- and long-term interest rates, which should increase asset prices and lower the borrowing costs of enterprises and families. In this sense quantitative easing is really just a continuation of "normal" monetary policy by moving up the yield curve and should have similar effects. But there are reasons to doubt that the usual elements of the monetary transmission mechanism will work under present circumstances.

US corporations are already sitting on an enormous pile of cash. Lower interest rates will not lead them to invest more. Lowering borrowing costs for families should help sustain house prices and consumption. But again, under current circumstances, the effect will be very limited because there are so few new home buyers. The usual transmission mechanism would be massive refinancing of existing mortgages, but this is now impossible because many are "under water" (the value of the house is lower than the mortgage). Higher stock prices should give another boost to demand, but this is likely to be limited as one cannot really say by how much quantitative easing will boost stock prices and only a very small part of any increase in stock prices stimulated by temporarily depressed medium-term bond yields will be consumed. The only channel which should work as usual thus remains the exchange rate.

Most observers thus agree that the new round of quantitative easing (QE II) should have a rather limited impact on the economy, but the standard models suggest that it should certainly be positive. However, this line of argument overlooks the fact that lower interest rates also mean lower incomes for investors, like insurance companies and ordinary people who have saved for their retirement. These rentiers will now have to reduce consumption because their income has gone down along with interest rates. The upshot is 
that one cannot exclude the case that the net effect of QE II might be to reduce demand in the USA.

This explains why the reaction to the new round of quantitative easing has been so hostile outside the USA: normally the impact of an easing of monetary policy on the rest of the world should be neutral - as income in the USA goes up, the rest of the world can export more to the USA. At the same time, the US dollar might depreciate, but the two effects could easily be of similar size, thus cancelling each other out. However, the emerging markets and countries whose economies are in a healthy state now perceive that QE II will only have a negative impact because it does not stimulate demand in the USA but will foster asset price bubbles everywhere else. Moreover, emerging markets have already left the recession behind and they do not need a further monetary stimulus.

The only area that might actually benefit from QE II is the euro area, because the depressed yields from US Treasuries are likely to stimulate the search for yields and the risk appetite of investors everywhere. These days the US Treasury can borrow at rockbottom interest rates. The interest rate on inflation-protected bonds has actually now become minus $0.5 \%$ for a five-year maturity! The US government is thus essentially being paid in real terms by investors to take their resources. This implies that investors have to look for any alternative that has at least a positive real yield. With Irish, Greek and other bonds now trading at yields around $8 \%$, investors might be tempted to take the plunge, trusting that in the case of trouble Europe would be ready to bail them out.

Will the emerging economies be able to isolate themselves from the wave of liquidity which the Federal Reserve is unleashing? Germany discovered how difficult this is during the 1960s and 1970s and resisted the trend of the Deutschmark first to appreciate and then to become an international reserve currency because it felt that the exportoriented German economy would suffer from the wide swings in the exchange rate that are the norm for global reserve currencies. Given the weakness of the other European currencies, however, and Germany's desire to keep markets open, there was very little that its authorities could do. As the Deutschmark became a major international reserve currency during the 1980s and 1990s, large gyrations in the dollar exchange rate thus at times had a rather large impact on the German economy. However, in the end the German economy adjusted and the country was able to preserve relative price stability even when inflation took off in the rest of the world.

Today the emerging markets, especially China, have taken the place of Germany (and Japan) in the 1960s and 1970s as the major emerging exporting nations - but with one difference: China manages its exchange rate tightly using pervasive capital controls and massive interventions. Given that China is the only major economy with widespread capital controls, China has created its own "exorbitant privilege": it can determine its exchange rate because all the other big nations do not have capital controls. A number of other, smaller, emerging economies are also toying half-heartedly with partial capital controls to keep their economies from appreciating. However, as in the case of Germany about 40 years ago, this is unlikely to be effective as partial controls in otherwise open financial markets cannot prevent a flood of "hot money", as it used to be called.

What is called currency wars is thus really a zero-sum game for the world's export markets, a continuation of monetary policy by other means. In the long run the winners may be those who do not try to fight the markets and resist the strength of their currencies even if this may mean a painful adjustment in their export sector in the short run. 